\title{
An RCA Analysis of Textiles and Clothing in Pakistan, India, and Bangladesh
}

\section{Khurram Shahzad*}

\begin{abstract}
This study focuses on the revealed comparative advantage analysis for Clothing and Textile sectors of Pakistan, India and Bangladesh. We have applied the Balassa's (1965) Index for the analysis. The revealed comparative advantage has been analyzed in two different ways: one static on the year 2010 and the other one dynamic based on 1980, 1990, 2000 and 2010. For the dynamic analysis, the average of the three previous years from 2010 were taken and used for revealed comparative advantage. The results show Pakistan's highest revealed comparative advantage for textiles over both India and Bangladesh. India has revealed a comparative disadvantage in textile in competition of Pakistan and Bangladesh. For clothing, Bangladesh has very dominant revealed comparative advantage when competing with Pakistan and India. Dynamic revealed comparative advantage indicates Pakistan has been gaining a comparative advantage in textiles since 1980 but with a declining percentage of textile export. Bangladesh has significantly gained a comparative advantage in clothing since the 1980s.
\end{abstract}

Keywords: Revealed Comparative Advantage, Textile, Clothing, Product Positioning, Balassa Index, Pakistan.

JEL classification: F10, F14, F15, O57.

\section{Introduction}

Comparative advantage in the production of a commodity implies greater returns to one country relative to the other. Although it can be measured by determining the relative pre-trade prices of the commodity in question, this computation is accompanied by difficulties (Mahmood \& Hajji, 2009). Balassa's (1965) concept of revealed comparative advantage (RCA) is, therefore, used extensively to analyze countries' comparative advantage in specific commodities as well as patterns of comparative advantage for commodities over time.

\footnotetext{
* Lecturer, School of Economics, Minhaj University, Lahore; PhD student, Pakistan Institute of Development Economics, Islamabad, Pakistan.
} 
Studying a country's patterns of trade is crucial in developing its trade policy. The comparative advantage of a particular commodity varies with time and the country's structural variations. This study uses an RCA index to examine the comparative advantage of producing textiles and clothing with respect to Pakistan, India, and Bangladesh. We concentrate on these two sectors for two reasons: first, because they account for a substantial part of the three countries' exports and, second, because very few studies in the literature have focused on textiles and clothing in the context of these countries.

In Pakistan, textiles and clothing comprise 52.5 percent of the country's total exports. For India and Bangladesh, the World Integrated Trade Solution database reports corresponding proportions of 11.3 percent and 88.1 percent, respectively. In studying the comparative advantage of these three countries with respect to textiles and clothing, we conduct a dynamic analysis of the last four decades.

\section{Literature Review}

Sinanan and Hosein (2012) calculate the RCA for Trinidad and Tobago, using three-digit export data for the period 1991-2008. The study also applies other tools to determine the change in comparative advantage, including Galtonian regressions, Markov chains, transition probability matrices, mobility indices, and Granger causality tests. The results indicate that Trinidad and Tobago should specialize in the export of petroleum products rather than nonenergy commodities.

Mahmood and Hajji (2009) compute the RCA index for Kuwait's nonpetroleum sector, dividing the country's products into six groups based on their RCA values (food, live animals, beverages and tobacco, crude materials, chemicals, and manufactured articles). While manufactured items, machinery, and transport appear to be losing their comparative advantage, other products indicate an improved RCA. The study also analyzes the intertemporal behavior of RCA for the period 1995-2002 and concludes that nonpetroleum products have emerged in response to global competitiveness.

Batra and Khan (2005) carry out an extensive analysis of two-digit sector-level and six-digit commodity-level data (based on the HS classification) for India and China to assess where their comparative advantage lies. The two countries are seen as comparable in terms of economy size, geography, and factor endowments. The study's factor 
intensity analysis indicates that both have a greater RCA in manufacturing, while the dynamic RCA analysis shows that India has a greater advantage in agriculture and allied products.

Serin and Civan (2008) examine Turkey's comparative advantage in the EU vis-à-vis Spain, Italy and Greece for the period 1995-2005. Using the RCA and comparative export performance indices, they find that Turkey has a strong comparative advantage in the region's fruit juice and olive oil markets. However, this trend has declined since 2000, which the authors associate with distortions between Turkey and the EU. Additionally, Turkey is found to have a comparative disadvantage in tomato production.

Akhtar, Zakir, and Ghani (2008) study the RCA for Pakistan's footwear industry for the period 2003-06. They show that the industry has moved from a comparative disadvantage to a comparative advantage, and is expected to grow. Hanif and Jafri (2008) construct an RCA index for the country's textiles sector and find that greater access to external finance has a strong, positive impact on the sector's export competitiveness.

Mahmood (2004) analyzes the comparative advantage of Pakistan's nonagriculture sector to determine which products have lost, gained, or maintained their comparative advantage. The RCA index shows that the textiles and clothing sectors have remained consistent over time, but are likely to face serious competition in the wake of trade liberalization, especially from China.

Utkulu and Seymen (2004) use seven different RCA indices to study Turkey's RCA at a sectoral level for the period 1990-2003. Of the 63 product groups they analyze, Turkey has a comparative advantage in only seven: clothing, vegetables and fruits, sugar, honey, tobacco, oil seeds, and textile yarn. All seven indices yield similar results. The study also looks at the impact of the customs union process on comparative advantage and competitiveness.

Fertő and Hubbard (2002) study comparative advantage patterns for the Hungarian agri-food sector during the 1990s. Using EU trade data, they construct four different RCA indices and find that the sector's RCA remains stable over this period. 


\section{Methodology}

We have seen that the literature relies heavily on Balassa's (1965) RCA index. This is calculated by dividing the share of exports of a particular commodity in the country's total exports by the share of exports of that commodity in total world exports. The value of RCA determines the country's comparative advantage or disadvantage for that commodity. A value greater than 1 indicates a comparative advantage and a value smaller than 1 indicates a comparative disadvantage.

The study's dynamic analysis of comparative advantage is based on four product groups, which represent that particular commodity's comparative advantage over time (see Appendix for more details). These product groups are listed below (see Mahmood, 2004; Mahmood \& Hajji, 2009):

- Competitively positioned products improve consistently over time and have an RCA that is greater than 1 in time $t$.

- Threatened products have an RCA that is greater than 1. However, it is inconsistent and deteriorates over time.

- Emerging products are expected to gain a comparative advantage in the future. They are further divided into two subcategories based on their RCA:

- Tier I products initially lack a comparative advantage but, over time, move toward gaining a comparative advantage.

- Tier II products have a greater comparative disadvantage than tier I products, but also indicate a potential shift toward comparative advantage over time.

- Weakly positioned products have a greater comparative disadvantage in that their comparative advantage deteriorates continuously over time.

- Tier I products have a revealed comparative disadvantage: their comparative advantage declines continuously over time.

- Tier II products have a greater RCA, which does not improve over time. 


\section{Data}

The data for this study is from the World Trade Database under the Standard International Trade Classification (SITC) scheme and spans the years 1980, 1990, 2000, and 2010. Textiles fall under SITC 65, which includes textile yarn, fabrics, and made-up articles. This is further divided into nine categories:

\begin{tabular}{ll}
\hline $\begin{array}{l}\text { SITC } \\
\text { Product } \\
\text { Number }\end{array}$ & \multicolumn{1}{c}{ Product Category } \\
\hline 651 & Textile yarn \\
652 & Cotton fabrics, woven (not including narrow or special fabrics) \\
653 & Fabrics, woven, of manmade textiles (not including narrow or special \\
& fabrics) \\
654 & Other textile fabrics, woven \\
655 & Knitted or crocheted fabrics (including tubular-knit fabrics, pile \\
& fabrics, and openwork fabrics) \\
656 & Tulles, lace, embroidery, ribbon, trimmings, and other small wares \\
657 & Special yarns, special textile fabrics, and related products \\
658 & Made-up articles, wholly or chiefly of textile materials \\
659 & Floor coverings, etc. \\
\hline
\end{tabular}

Clothing falls under SITC 84 and includes articles of apparel and clothing accessories. These are further divided into eight categories:

\begin{tabular}{ll}
\hline $\begin{array}{l}\text { SITC } \\
\text { Product } \\
\text { Number }\end{array}$ \\
\hline 841 & $\begin{array}{l}\text { Not knitted or crocheted: men's/boys' coats, capes, jackets, suits, } \\
\text { blazers, trousers, shorts, and shirts }\end{array}$ \\
842 & $\begin{array}{l}\text { Not knitted or crocheted: women's/ girls' coats, capes, jackets, suits, } \\
\text { trousers, shorts, shirts, dresses, and skirts }\end{array}$ \\
843 & $\begin{array}{l}\text { Knitted or crocheted: men's/boys' coats, capes, jackets, suits, blazers, } \\
\text { trousers, shorts, and shirts }\end{array}$ \\
844 & $\begin{array}{l}\text { Knitted or crocheted: women's/girls' coats, capes, jackets, suits, } \\
\text { trousers, shorts, shirts, dresses, and skirts }\end{array}$ \\
845 & $\begin{array}{l}\text { Articles of apparel, of textile fabrics, whether or not knitted or } \\
\text { crocheted } \\
\text { Clothing accessories, of textile fabrics, whether or not knitted or } \\
\text { crocheted (other than those for infants) } \\
\text { Articles of apparel and clothing accessories of other than textile } \\
\text { fabrics; headgear of all materials }\end{array}$ \\
\hline
\end{tabular}




\section{Analysis and Interpretation of Results}

This section calculates the RCA for Pakistan, India, and Bangladesh and then conducts a dynamic RCA analysis for the three countries. Table 1 gives the RCA values for textiles and clothing for 2010. Pakistan has the highest RCA for textiles (22.26) while India has the lowest (3.44). This implies that Pakistan has the strongest comparative advantage in producing textiles relative to the other two countries in the year 2010.

Table 1: RCA for textiles and clothing, 2010

\begin{tabular}{lcc}
\hline Country & RCA for textiles & RCA for clothing \\
\hline Pakistan & 22.26 & 7.98 \\
India & 3.44 & 2.16 \\
Bangladesh & 3.99 & 35.46 \\
\hline
\end{tabular}

Source: Author's calculations.

Bangladesh has the highest RCA for clothing (35.46), followed by Pakistan (7.98) and India (2.16). Clearly, Bangladesh has a strong comparative advantage in the production of clothing compared to Pakistan and India, while Pakistan has a comparative advantage over India. While all three countries have a comparative advantage in this product category, Bangladesh has a very strong RCA over the other two. Moreover, in both cases (textiles and clothing), India has a revealed comparative disadvantage relative to Pakistan.

The dynamic RCA analysis for the selected countries is from decade to decade, using the first year of each decade (1980, 1990, 2000, and 2010). Table 2 gives the dynamic RCA for Pakistan, India, and Bangladesh along with their respective shares of textiles and clothing as a percentage of total merchandise.

The RCA for textiles in Pakistan's case increased between 1980 (12.38) and 2010 (22.26). Textile exports accounted for almost 33.5 percent of total merchandise exported in 1980, with this share increasing to 36.7 percent in 2010 and reaching 50.2 percent in 2000. Although textiles register a consistent rise in RCA, the sector's percentage share of exports has declined from 50.2 percent in 2000 to about 36.7 percent in 2010.

This decline could be due to the energy crisis Pakistan has faced since 2007, where the electricity shortfall has been responsible for slowing 
down growth in Pakistan's manufacturing sector while the unavailability of gas in winter has lowered production levels in the textiles sector. Poor governance may also account for the lack of effective policies for the textiles sector.

Table 2: Dynamic RCA analysis

\begin{tabular}{llrrrr}
\hline Country & \multicolumn{1}{c}{ Division } & $\mathbf{1 9 8 0}$ & $\mathbf{1 9 9 0}$ & $\mathbf{2 0 0 0}$ & $\mathbf{2 0 1 0}$ \\
\hline Pakistan & 12.38 & 15.67 & 20.93 & 22.26 \\
& RCA for textiles & 33.48 & 47.42 & 50.20 & 36.66 \\
& \% Share of textiles in total merchandise & 1.98 & 5.76 & 7.75 & 7.98 \\
& RCA for clothing & 3.95 & 18.05 & 23.75 & 18.35 \\
& \% Share of clothing in total merchandise & 5.63 & 4.10 & 5.50 & 3.44 \\
India & RCA for textiles & 15.21 & 12.13 & 13.20 & 5.67 \\
& \% Share of textiles in total merchandise & 3.93 & 4.50 & 4.60 & 2.16 \\
& RCA for clothing & 7.84 & 14.08 & 14.07 & 4.96 \\
& \% Share of clothing in total merchandise & 20.19 & 6.78 & 2.56 & 3.99 \\
Bangladesh & RCA for textiles & 54.58 & 20.51 & 6.15 & 6.58 \\
& \% Share of textiles in total merchandise & 0.11 & 12.27 & 25.88 & 35.46 \\
& RCA for clothing & 0.22 & 38.48 & 79.30 & 81.59 \\
\hline
\end{tabular}

Source: Author's calculations.

India's RCA values for both textiles and clothing decrease over time. The RCA for textiles was a little over 5.6 in 1980 and declined to just over 3.4 in 2010. The share of textile exports fell from 15.2 percent in 1980 to just under 5.7 percent in 2010. The RCA for clothing was a little over 3.9 in 1980 and fell below 2.2 in 2010 . The share of clothing exports was over 7.8 percent in 1980, but declined to less than 5 percent in 2010 . Overall, the dynamic RCA analysis does not give a promising picture of India's textiles and clothing sectors, where the exports of both have declined continuously over time.

The data for Bangladesh shows a decline in the RCA for textiles from 1980 (20.19) to 2010 (3.99), reflecting a decline in the country's comparative advantage in this sector. Textile exports accounted for almost 54.6 percent of total merchandise exported to the world in 1980, but this share had fallen significantly by 2010 to just under 6.6 percent.

On the other hand, Bangladesh appears to have performed very well in the clothing sector from 1980 to 2010, which is likely associated with its decision to pursue export-oriented rather than import-substitution industrialization. The country's strategy has focused specifically on the 
readymade garments sector (which, in this study, falls under clothing). Its share of textile exports has, however, declined as a probable result of constant flooding and a decline in world demand (see Spinanger, 1987).

Bangladesh registers a negligible RCA for clothing in 1980 (0.11), where the sector accounts for just over 0.2 percent of total merchandise exported. However, the country's revealed comparative disadvantage improves significantly over time and, by 2010, its RCA has risen to 35.46 and its share of exports to almost 81.6 percent (Table 2).

Figures 1 and 2 plot the RCA for clothing and textiles, respectively, for Pakistan, India, and Bangladesh, enabling a comparison between the two product groups. Figures 3 and 4 plot the respective shares of clothing and textiles for these countries over the decades.

Figure 1: RCA for clothing, 1980-2010

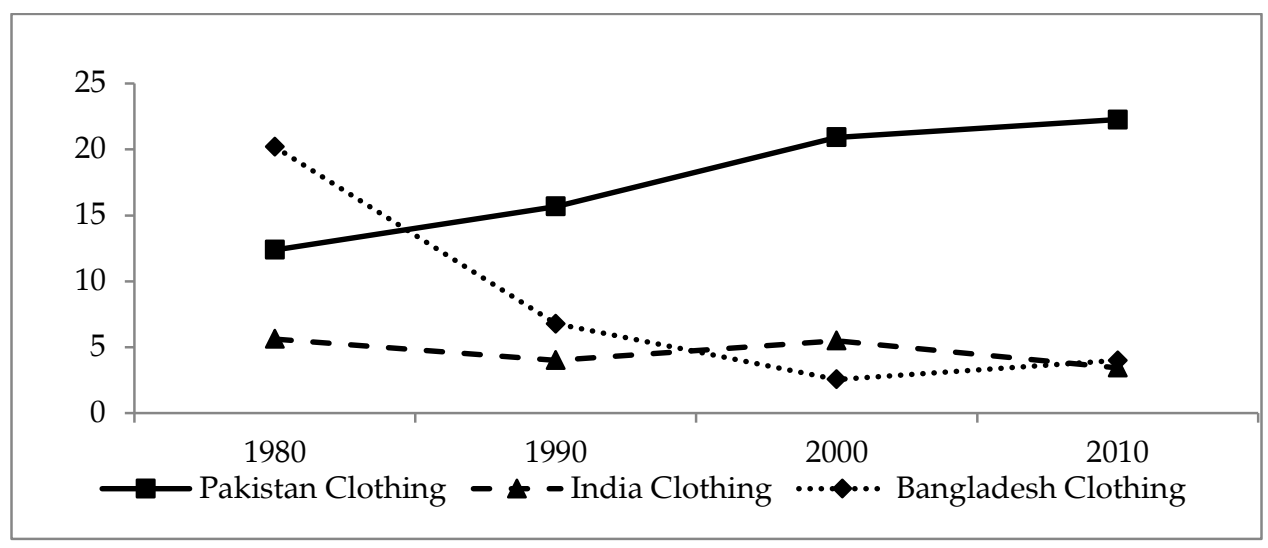

Figure 2: RCA for textiles, 1980-2010

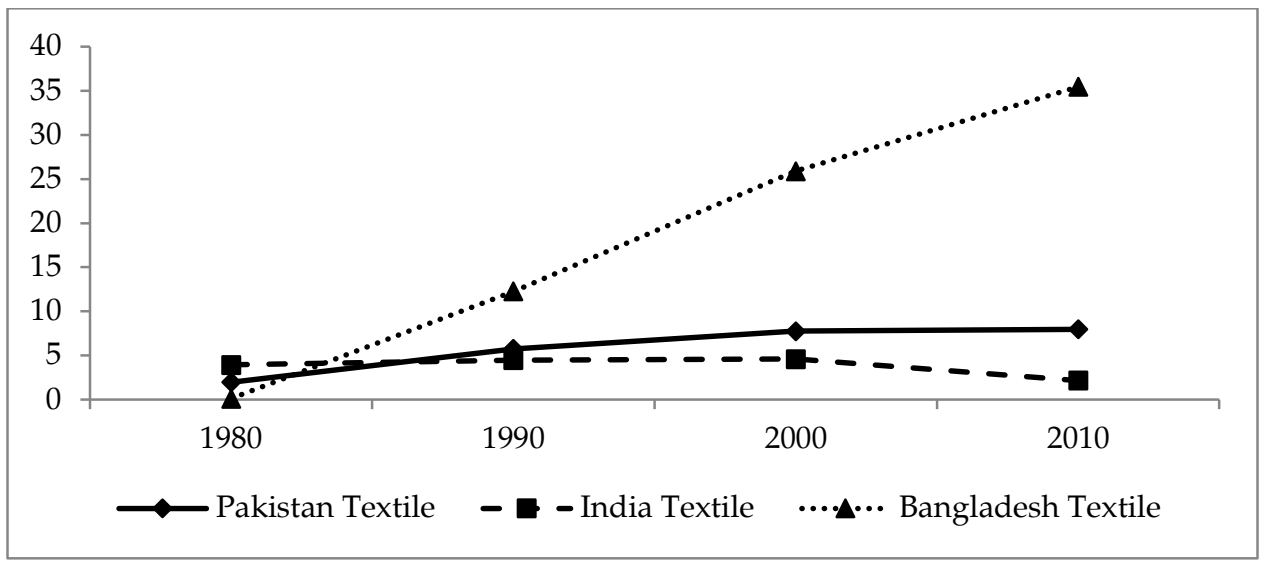


Figure 3: Share of clothing in total merchandise

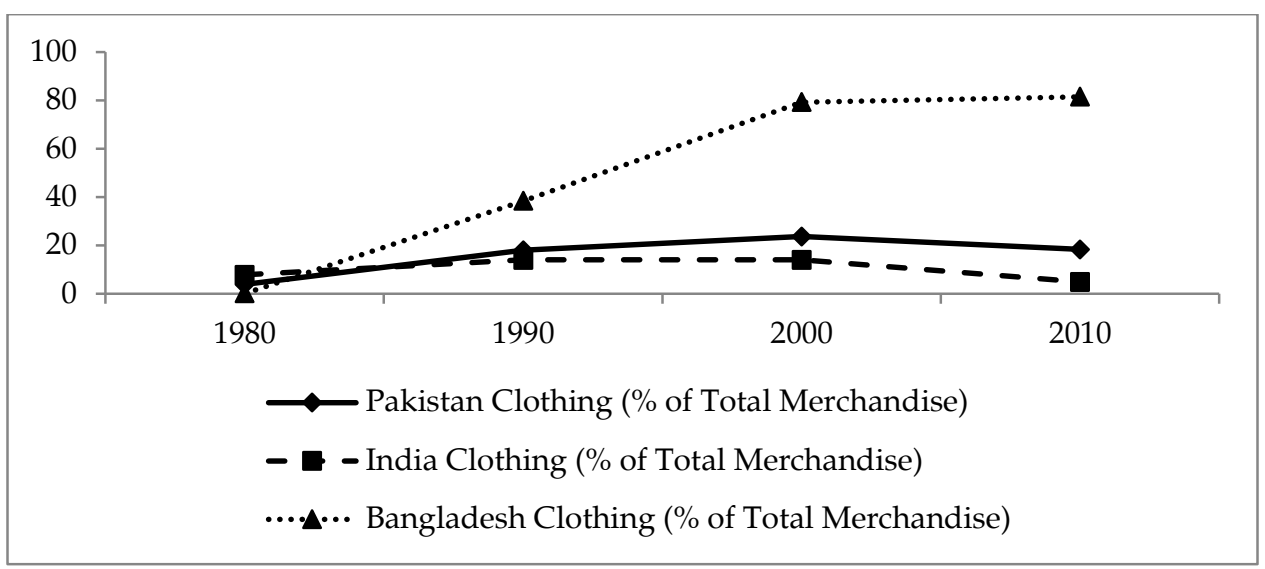

Figure 4: Share of textiles in total merchandise

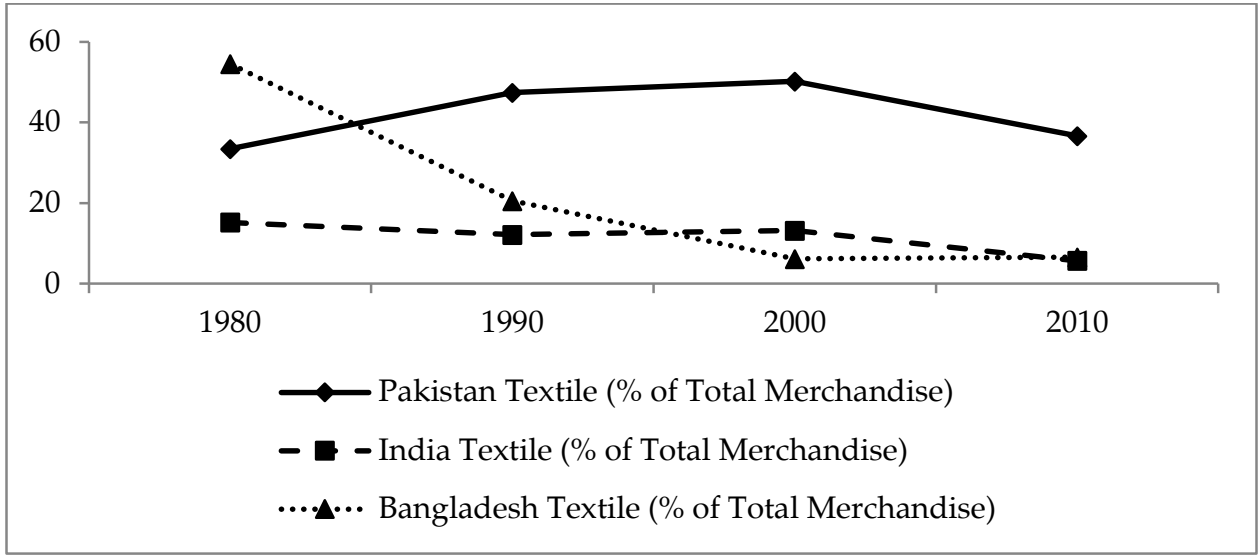

Pakistan's RCA for textiles in 2010 is 22.26, indicating a difference of -0.89 from the corresponding previous three-year average (Table 3). Thus, although their RCA value is greater than 1, textiles are classified as threatened products because the value does not improve over time. Moreover, the percentage share of textile exports in total merchandise has declined between 2000 and 2010. Clothing follows a similar trend. Its RCA is also greater than 1, but the difference in values between 2010 and the previous three-year average is -0.28 . This demonstrates that, over time, clothing in Pakistan has become a threatened product group.

Both Indian textiles and clothing qualify as threatened product groups with an RCA greater than 1, but a negative value for the 
difference between the RCA for 2010 and the corresponding previous three-year average ( -0.05 and -0.52 for textiles and clothing, respectively).

In the case of Bangladeshi textiles, the difference between the RCA for 2010 and the previous three-year average is -0.08 (the RCA is still greater than 1). Again, this brings the sector within the threatened products category. The clothing sector presents a different case, however, and remains strongly competitive relative to Pakistan and India. The RCA for clothing is 35.46 and the difference between the RCA for 2010 and the corresponding previous three-year average is 4.19 (greater than 0 ). This implies that the product group enjoys a strong competitive position in the international market.

Table 3: Difference between RCA values

\begin{tabular}{lcc}
\hline Country & Division & RCA $\mathbf{2 0 1 0}-$ RCA $\left(\sum_{\boldsymbol{i}=\mathbf{2 0 0 7}}^{\mathbf{2 0 0}} \boldsymbol{x i} \mathbf{3}\right)$ \\
\hline Pakistan & Textiles & -0.89 \\
\multirow{3}{*}{ India } & Clothing & -0.28 \\
& Textiles & -0.05 \\
\multirow{2}{*}{ Bangladesh } & Clothing & -0.52 \\
& Textiles & -0.08 \\
& Clothing & 4.19 \\
\hline
\end{tabular}

Source: Author's calculations.

\section{Conclusion}

The study's static and dynamic analyses of textiles and clothing for the selected countries reveal that Pakistan has a comparative advantage in both product groups, but a revealed corporative advantage in textiles. However, neither group has improved over time and are thus both classified as threatened products. India fares worst with a smaller RCA in both textiles and clothing relative to Pakistan and Bangladesh over time. Both product groups are classified as threatened products. Finally, textiles in Bangladesh fall under the threatened products category, but the country's clothing sector has improved significantly in terms of RCA. 


\section{References}

Akhtar, N., Zakir, N., \& Ghani, E. (2008). Changing revealed comparative advantage: A case study of footwear industry of Pakistan. Pakistan Development Review, 47(4), 695-709.

Balassa, B. (1965). Trade liberalization and "revealed" comparative advantage. The Manchester School, 33(2), 99-123.

Batra, A., \& Khan, Z. (2005). Revealed comparative advantage: An analysis for India and China (Working Paper No. 168). New Delhi: Indian Council for Research on International Economic Relations.

Fertő, I., \& Hubbard, L. J. (2002). Revealed comparative advantage and competitiveness in Hungarian agri-food sectors (Discussion Paper No. 2002/8). Budapest: Institute of Economics, Hungarian Academy of Sciences.

Hanif, M. N., \& Jafri, S. K. (2008). Financial development and textile sector competitiveness: A case study of Pakistan. South Asia Economic Journal, 9(1), 141-158.

Mahmood, A. (2004). Export competitiveness and comparative advantage of Pakistan's non-agricultural production sectors: Trends and analysis. Pakistan Development Review, 43(4, Pt. II), 541-561.

Mahmood, Z., \& Al-Hajji, R. (2009). Revealed comparative advantage of non-petroleum products in Kuwait. NUST Journal of Business and Economics, 2(1), 32-41.

Serin, V., \& Civan, A. (2008). Revealed comparative advantage and competitiveness: A case study for Turkey towards the EU. Journal of Economic and Social Research, 10(2), 25-41.

Sinanan, D., \& Hosein, R. (2012). Transition probability matrices and revealed comparative advantage persistence in a small hydrocarbonbased economy. West Indian Journal of Engineering, 34(1/2), 16-29.

Spinanger, D. (1987). Will the Multi-fiber Arrangement keep Bangladesh humble? The World Economy, 10(1), 75-84.

Utkulu, U., \& Seymen, D. (2004, September). Revealed comparative advantage and competitiveness: Evidence for Turkey vis-à-vis the EU/15. Paper presented at the European Trade Study Group's Sixth Annual Conference, Nottingham, UK. 


\section{Appendix}

\begin{tabular}{|c|c|}
\hline Product positioning & Restrictions \\
\hline $\begin{array}{l}\text { Competitively positioned } \\
\text { products }\end{array}$ & $\begin{array}{l}\text { - } \mathrm{RCA}_{t}^{i}>1 \\
\text { - } \mathrm{RCA}_{t}^{i}-\mathrm{RCA}_{\text {average of previous three years from } t}^{i}> \\
\quad 0\end{array}$ \\
\hline Threatened products & $\begin{array}{l}\text { - } \mathrm{RCA}_{t}^{i}>1 \\
\text { - } \mathrm{RCA}_{t}^{i}-\mathrm{RCA}_{\text {average of previous three years from } t}^{i}< \\
0\end{array}$ \\
\hline \multirow[t]{2}{*}{ Emerging products } & $\begin{array}{l}\text { Tier I } \\
\text { - } \mathrm{RCA}_{t}^{i}<1 \\
\text { - } \mathrm{RCA}_{t}^{i} \geq 0.5 \\
\text { - } \mathrm{RCA}_{t}^{i}-\mathrm{RCA}_{\text {average of previous three years from } t}^{i}> \\
\quad 0\end{array}$ \\
\hline & $\begin{array}{l}\text { Tier II } \\
\text { - } \mathrm{RCA}_{t}^{i}<0.5 \\
\text { - } \mathrm{RCA}_{t}^{i}-\mathrm{RCA}_{\text {average of previous three years from } t}^{i}> \\
\quad 0\end{array}$ \\
\hline \multirow[t]{2}{*}{ Weakly positioned products } & $\begin{array}{l}\text { Tier I } \\
\text { - } \mathrm{RCA}_{t}^{i}<1 \\
\text { - } \mathrm{RCA}_{t}^{i} \geq 0.5 \\
\text { - } \mathrm{RCA}_{t}^{i}-\mathrm{RCA}_{\text {average of previous three years from } t}^{i} \\
\quad 0\end{array}$ \\
\hline & $\begin{array}{l}\text { Tier II } \\
\text { - } \mathrm{RCA}_{t}^{i}<0.5 \\
\text { - } \mathrm{RCA}_{t}^{i}-\mathrm{RCA}_{\text {average of previous three years from } t}^{i}< \\
\quad 0\end{array}$ \\
\hline
\end{tabular}

